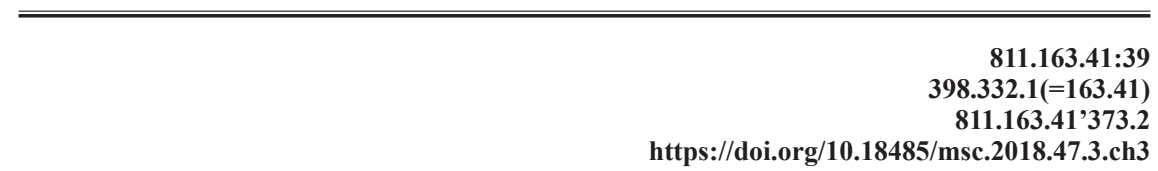

Снежана П. ВУЧКОВИЋ*

Филолошки факултет

Универзитета у Београду

\title{
ЕТНОЛИНГВИСТИЧКЕ КАРАКТЕРИСТИКЕ НЕКИХ ХРОНОНИМА ПРОЛЕЋНОГ ОБРЕДНОГ ЦИКЛУСА
}

\begin{abstract}
У раду се анализирају хрононими масленичког, великопосног и ускршњег обредног циклуса у чијим називима су одражене неке архаичне особине српског језика и културе. Испитују се номинациони модели у којима ови оними настају, осветљавају се узроци њихове језичке и културне деетимологизације, актуелизује важност проучавања етнолингвистичког контекста у којем ове речи настају и функционишу, као и проучавања односа претхришћанских и хришћанских слојева у семантичким и симболичким садржајима ове лексике.
\end{abstract}

Кључне речи: народни календар, хрононими, етнолингвистика, номинациони и културни модели

1.1. Етнолингвистички приступ проучавању обредне и обичајне терминологије има већ дужу традицију у словенским етнолингвистичким студијама. Особена улога ове лексике, по речима Светлане Толстој - која је о теоријским аспектима етнолингвистичког приступа обредној лексици (заједно са Н. Толстојем) највише и писала - састоји се у томе што она истовремено припада и језику и култури. Језику, јер је потчињена законитостима формалне и семантичке организације лексичког система, законима номинације, парадигматским односима који унутар њега владају, а култури - јер има особене културне функције и у вези је са другим елементима њеног семиотичког језика (акционалним, предметним, личним, локативним, временским) (Толстој/Толстој 2013: 167). Обредном лексиком пролећно-летњег календарског циклуса бавила се најсистематичније Т. А. Агапкина у књизи Мифопоэтические основы славянского народного календара. Весенне-летный иикл (Москва, 2002). Ауторка је на основу веома репрезентативног материјала, који је укључивао хронониме, називе обреда, њихових комплекса, ритуал-

*snezanabaukvuckovic@gmail.com 
них предмета, радњи, митолошких персонификација, лица која врше или над којима се врше ритуалне радње - реконструисала један веома важан сегмент старе словенске духовне културе и издвојила читав комплекс посебних митопоетских сижеа и мотива (в. поглавље Указатель основных тем, сижетов, мотивов и ритуальных действии, 758-780) који указују на то да је традиционални словенски календар био истовремено и календар природе, календар човекове привредне (пре свега земљорадничке и сточарске) делатности, као и календар његовог социјалног битка. Те основне теме или митопоетске доминанте (Агапкина 2002: 21-22), које карактеришу одређене периоде овог обредног циклуса и манифестују се у свим његовим жанровским формама (акционалним, предметним, личним, просторним, временским, као и у метајезику фолклора) - свој одраз налазе и у хрононимима, тј. називима посебних празничних дана или периода народног календара.

Хрононими представљају важан слој у проучавању обредне лексике будући да се трагом њихових језичких (номинациона, симболичка) или културних функција ${ }^{1}$ могу открити информације важне за разумевање њихових номинационих модела и за реконструкцију неких од најважнијих основа старе словенске духовне културе. Претхришћански слој ове лексике открива како је она, у историјски и културно одсудном сусрету са младом хришћанском културом, претрпела преображај у којем су многе њене митопоетске константе наставиле да трају и да се обновљене понављају носећи у другачијем облику своје старе значењске и симболичке слојеве.

1.2. У овом раду ми ћемо се осврнути на етнолингвистички аспект неких хрононима старог српског пролећног обредног циклуса, првенствено оних чија је унутрашња форма ${ }^{2}$ за просечног носиоца данашњег српског језика непрозирна и не указује било на њихову првобитну формалну или семантичку мотивисаност било на семантичко-симболичку парадигму самог празника на који се односе. Уз ове хронониме анализираће се и други мотивационо прозирни називи. Циљ рада је издвајање претпостављених номинационих модела, осветљавање узрока који доводе до деетимологизације неких од ових лексема, као и анализа неких њихових културних функција. Праћење етнолингвистичких карактеристика њихове номинације указаће и на сложено преплитање претхришћанских и хришћанских културних тради-

${ }^{1}$ С. Толстој међу овим функцијама издваја: конзервирајућу (мит, веровање, обред су изгубљени, а термин је остао), кондензујућу (термин - скраћени текст), архаизујућу (ритуална непроменљивост термина), сакралну (ритуализација реалија које су термином утврђене), интерпретативну (термин мотивише обредну радњу, њен дубински смисао), продуктивну (културна „етимологизација” термина рађа ритуал, веровање, обредну забрану итд.) (Толстој/Толстој 2013: 180).

2 Термином унутрашња форма речи ознава се у етимолошким и историјско-семантичким истраживањима однос између морфемске структуре речи и њеног значења. Унутрашња форма речи одражава њену првобитну семантичку и формалну мотивисаност. Она може током времена бити затамњена (деетимологизована) из различитих разлога (губљења мотивационе речи, кидања творбених веза, регуларних и аналогијских историјских фонетских промена, даљег развитка значења преосмишљавањем под утицајем другачијег културног модела и сл.). (в. Ж. Ж. Варбот и А. Ф. Журављев, Краткий понятийно-терминологический справочник по этимологии и исторической лексикологии. <http://etymolog.ruslang.ru/doc/etymology_terms.pdf>. 3. 3. 2016). 
ција и основних митопоетских и културних доминанти које су у семантици и симболици неких од ових онима остале до нашег времена повезане.

Разматране хронониме ћемо представити следећи њихово календарско хронолошко наступање у оквиру масленичког, великопосног и ускршњег циклуса, не узимајући притом у обзир оне који представљају изведенице од имена хришћанских светитеља нити називе канонских хришћанских празника.

Као извори грађе послужили су пре свега компендијуми, какав је $C p n-$ ски митолошки речник (СМР 1970), речник Словенске древности (СД), Материјали за етнолингвистичко изучавање балканословенског ареала А. А. Плотњикове (Плотњикова 2009), али је коришћена и грађа из веома богате збирке српских етнолошких извора - какав је на пример Српски етнолошки зборник (СЕЗб) или Гласник Етнографског музеја у Београду (ГЕМБ), те материјал из посебних етнолошких или лингвистичких студија које доносе лексику календара, односно календарског фолклора.

\section{1. Масленички (покладни) обредни циклус}

Масленички (покладни) обредни циклус, назван тако по празничном периоду који пада у недељу пре Великог поста (упор. рус. Масленица, укр. месниия, бел. масленіса, чеш. masopust, pusti teden, срп./хрв. Покладе, буг. Сирна неделя, мак. Проштена недеља), у народном календару представља границу која дели зимски од пролећно-летњег обредног циклуса, тј. месојеђе од дана Великог поста. Карактерише га низ обредних радњи какве су паљење обредних лустративних ватри, буктиња или стрела; обреди и магијске радње везане за прогон вештица (и њихово симболично спаљивање); обичаји и забране оријентисани на буђење биљног и животињског света тј. на раст и плодност културног растиња, те фертилитет животиња и људи; карневалске и маскарадне игре; обичаји „праштања” (у функцији успостављања нарушених социјалних норми); иницијацијски и оргијастички обреди праћени нарушавањем социјалних и етичких правила и рутуалним обилним узимањем мрсне хране, итд. Покладе се завршавају првим даном Великог поста, који је сматран даном очишћења од грехова и масне хране (СД 3: 194-199).

У српским народним говорима општи назив за овај празнични период је Покладе, хрононим који се везује и за неке друге празничне периоде (нпр. Ускршње, Божићне, Петрове и др.) и односи се на обреде, обичаје или гозбе уочи већих постова. На исти празнични период (седмицу) односе и називи Бела недеља, Сирна недеља (Сиропусна, Сирнииа), ${ }^{3}$ Гладна недеља, док се последњи дан ове седмице назива Беле покладе, Покладе, Прочка, Проште-

\footnotetext{
${ }^{3}$ Мотивационо прозиран назив према карактеристичној храни која се узима у овом периоду и коју чине млечни производи (СМР: 268).
} 
не покладе 4 (Плотњикова 2009: 103). Бројност наведених назива сведочи о томе да су различите одлике етнокултурног контекста овог празничног периода биле ономасилошка основа за наведене хронониме. ${ }^{5}$

Покладе. Назив је данас мотивационо непрозиран јер је под утицајем синонимичних глагола ставити, метнути стари псл. глагол *klasti, klado apхаизиран и чува се само као основа неких његових деривата (упор. срп. клад „арх. 1. закопано, сакривено благо; 2б. оно што је дато на чување”, клада „1. одсечен, неотесан комад стабла, балван, трупац, пањ; цепаница" (РСАНУ 9: 530), срп. дијал. приклад - део огњишта „на који се наслоне главње да боље догоре” (Тројановић 1930: 270); буг. клада „гомила, хрпа”, кладни „покладна обредна ломача" (Плотњикова 2009: 104); рус. клад „драгоцености које су остављене, сакривене негде”, клад(б)ище „гробље”, приклад „гроб”; блр. клады „погребна хумка, гробље”, итд. (ЭССЯ 9: 178-179)). Пажњу привлаче и лексеме из староруског корпуса Срезњевског: струс. клада 1. „брвно, већи комад дрвета, балван, трупац (на који се што може ставити)"; 2. колода „издубљен комад дрвета у који су стављани мртви”; 3. „погребна ломача, костер тј. купа дрва, грана које се користе за кремацију": творАхог кАадог

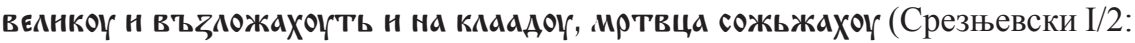
1211). Значења наведених лексема, као и горе наведени етнокултурни подаци о паљењу обредних огњева карактеристичном за Покладе, упућују на могућу ономасиолошку везу назива овог празника са паљењем обредних ватри које су за покладно време биле карактеристичне и које су имале различите функције (лустративне, апотропејске, профилактичке и сл.). Оне су у српским народним говорима различито називане: алалија, олалија, привег/привек/nривеј, марга, света ватра, велика ватра, освећена ватра, љевка, првеци, ранило, рана, крес, каравештица, крлевештица, калавештица (Плотњикова 2009: 101-104). Да је сам, у српском етнолошком корпусу непотврђен, назив клада „обредни огањ” могао стајати у вези са глаголом *klasti „ставити, метнути; наслагати" - упућује семантички паралелизам са њему синонимним девербативом ломача, јер и један и други појам подразумевају наслагану купу већег комада дрвећа (клада, пањева, цепаница), али и други материјал: изломљено и наслагано грање, кору дрвећа, остатке сувог културног растиња, суву лоза, остатке обредне хране, старе употребне или ритуалне предмете итд. (о етнокултурном контексту в. Агапкина 2002: 674-678).

Бела недеља. Аутори Српског митолошког речника назив овог хрононима доводе у везу са обичајима који припадају култу мртвих, тј. са старим народним веровањима да у овом периоду мртви оживљавају и крећу се међу живима (CMP: 21). Бела боја у овом случају не носи позитивно сакрално зна-

\footnotetext{
${ }^{4}$ Називи Прочка и Проштена недеља мотивисани су обичајем „праштања”. У њему су учествовали и појединци и целе сеоске заједнице, а био је симболично усмерен на успостављање нарушеног социјалног поретка и његових норми.

${ }^{5}$ У балканословенском ареалу функционишу још неки називи за исти празнични период: упор. мак. Проштена недеља, карневал; буг. Сирна неделя, Сирница, Сиреница, Сирни заговезни, Сирни заговелки, Прочшани поклади, Прочка, Пустовете, Ората, Орадие; рум. Săptămîna

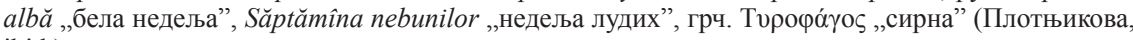
ibid.). 
чење засновано на природној и когнитивно јасној вези са дневним светлом, Сунцем, светом живих, сакралном сфером (упор. бели свет, не види ни белог бога), већ се поима као нешто што је лишено боје, празно и пусто (Раденковић 1996: 286), те постаје основом симболизације за супротну семантичку сферу - бела, као боја жалости, била је у старини позната не само словенским, него и другим индоевропским народима. Зељењин $(1995: 50,53)$ наводи да се у источнословенској фолклорној традицији бело асоцира са загробним светом, те се у белом појављују нечисти покојници, русалке и друге митолошке персонификације.

Назив Бела недеља није, међутим, био везан само за празнике предускршњег цилуса. На југозападу Србије (Пештер) назив се односи на недељу после празника Тројице. За овај календарски период био је везан низ обредних поступања акционално усмерених на заштиту од града. Етнографски извори бележе да се тада није радило у пољу, није прано бело рубље нити се белило платно - да се не „не бели” (Костић 1988/89: 102). Агапкина истиче да су бели дани и недеље били карактеристични за читав балкански ареал и да се три недеље (масленичка, претпасхална, тројичка) у народним говорима називају „белима”. Све их одликује обредно поступање усмерено на магијску заштиту од града. Срби у Такову „белим” називају седам четвртака (од Страсног четвртка до Вазнесења), када се празновало ради заштите од града (Агапкина 2002: 337). Ови етнокултурни подаци упућују на једну од културних функција обредних хрононима, ону која почива на принципу етимолошке магије (народне етимологије), по којем сам обредни термин мотивише и генерише обредну радњу (Толстој 2008: 228).

\section{2. Великопосни обредни циклус}

У етнографских студијама недеље (седмице) Великог, Ускршњег или Часног поста најчешће се називају Чиста, Пачиста, Крступоклона, Средопосна, Глува/Светла, Цветна и Велика/Страстна седмица (Шкарић 1939: 92-93; Петровић 1948: 239). Прелаз од „нечистог” времена масленичког периода (са фриволним понашањем, играма, карневализацијом простора и времена) ка „чистом” времену Пасхе одвијао се кроз телесно и духовно очишћење током Великог поста, када је забрањена употреба мрсне хране, полних односа, весеља (посебно прве и последње великопосне седмице) (СД 5: 552). Као и претходну групу хромонима, и ове карактерише постојање више назива за један исти празнични период (или дан) у зависности од тога која је особеност датог етнокултурног контеста узета за основу номинације. Поред тога, постоји и извесна неодређеност у погледу временских периода на које се ови хрононими односе, што може бити последица временског неподударања народног и хришћанског календара. ${ }^{6}$

\footnotetext{
${ }^{6}$ Толстој 1988: 119-132.
} 
Чиста недеља. Прва седмица Великог или Ускршњег поста. Њен назив је у вези са културном симболиком придева чист у којој су синкретизована како физичка тако и религиозно-духовна значења овог придева. Карактерише је низ обредних радњи са заједничким мотивом телесног и ритуалног очишћења (искувавање посућа, паљење буњишта, шишање и бријање мушкараца, купање, пост и др., СMP: 306). Пошто су уочи ове недеље биле Покладе, наведене радње се предузимају као припрема за дуг посни период који следи и који овом недељом почиње. Етнолози сведоче да се у Чистој недељи, од Беле недеље до Тодорове суботе, ничило или наничило тј. јело само једанпут дневно (Шкарић 1939: 391). Данас се назив овог празника доводи у везу са хришћански конотираним метафоричним значењима придева чист - „безгрешан, непорочан, неоскврњен”, а у богослужбеним текстовима који се током ове седмице читају на литургији преовладава тема очишћења од грехова.

Поимање чистог, односно нечистог било је, међутим, и у претхришћанској старини везано са нечим што носи позитиван, односно негативан аксиолошки предзнак и било је изразито сакрализовано. „Чисто” је у обредној сфери увек позитивно аксиолошки обележено и тиче се не само физичког и духовног аспекта човековог битка, већ и просторне и временске димензије света који га окружује (ритуално чисти/нечисти предмети или локуси; чисто/нечисто растиње и животиње; чисти и нечисти дани, итд., СД 5: 548-552). Семиотичка и културно-симболичка бинарност ових опозиција имала је одраза и на обредно поимање времена. Време живота стоји насупрот времену смрти, па се у народном календару смењују нечисти (некритени) дани, ритуално повезани са култом мртвих (масленички и тројички/русалски обредни циклус) и чисти - када су обичаји прописивали физичко и духовно очишћење (великопосни циклус: Чиста недеља, Чисти понедељак, Чисти четвртак). Хришћанство је ове старе духовне и религиозне концепте само обогатило хришћанским мотивима греха и очишћења, стара сакралност је добила нове нивое тумачења, али су многе обредне радње наставиле да трају и даље у склопу официјалне религиозне културе. Оне су се сада схватале више као знак извесне друштвене, традицијске укорењености него као жеља да се у додиру са нуминозним и елементарним (ватра и вода као средство очишћења, упор. укр. Помывалный понедилок), у обредима који су пратили смењивање космичких, природних циклуса (зима-пролеће) - сажме, синтетише и симболично представи људска мера једне више религиозне потребе.

Прва недеља Ускршњег поста се у ареалу балканских језика назива још и Тодорова недеља (југоисточна Србија); буг. Тодорова неделя, Гладна неделя, Черна неделя, Суха неделя, Луда неделя, Празна неделя; рум. Sёрtămîna neagră „црна недеља” (Плотњикова 2009: 105).

Назив Тодорова недеља припада хришћанском слоју ових хрононима jep је био мотивисан именом хришћанског светитеља Св. Теодора Тирона чији се празник се у суботу ове недеље слави. За балканску народну традицију карактеристична је митологизација овог светитеља који сматран заштитником стоке, нарочито коња (упор. срп. Коњски великден, буг. Конска 
тудурииа - Тодорова субота - Плотњикова 2009: 106) и довођен често у везу са „нечистим” покојницима чију персонификацију светитељ и његови коњи представљају (СД 5: 280). Међутим, хрононими са атрибутима гладна, суха, празна, ${ }^{7}$ луда, ирна улазе у круг хрононима овог обредног циклуса који одражавају старе претхришћанске етнокултурне представе повезане са мотивом „лошег”, култно нечистог календарског периода. Он је, уз неке друге теме и мотиве - повратак и оживљавање мртвих, присуство хтонских бића у свету живих, очишћење, изгон демона итд. - био део етнокултурног концепта тзв. прелазног времена. У годишњим обичајима одражена је заправо идеја о цикличном обнављању света (теорија „вечног враћања” М. Елијадеа), ${ }^{8}$ која се у структури народног календара огледа у постојању утврђених временских циклуса и тзв. „прелазних”, „кризних”, „,аморфних” периода у којима долази до поновог успостављања нарушеног поретка како у природи, тако и у људској заједници (Агапкина 2002: 31-32). Етнокултурна слика овог календарског периода одражена је у хрононимима који садрже негативну вредносну семантичку карактеристику: упор. нпр. Хрома недеља / Трапава недеља - друга недеља Ускршњег поста; народна веровања доводе је у везу са мистичним хромим коњима Св. Теодора Тирона који се у ово време славио 9 (СМР: 298, Босић 1996: 187, 224); Глува недеља - пета или прва седмица Ускршњег поста (Д. Ђорђевић 1958: 37); карактерише је низ ритуалних забрана које се односе на песму, свирку или какво весеље и празновање „од глувоће”, тј. да се не оглуви или да се не добију ушне болести (Филиповић 1939: 391; Мршевић-Радовић 2008: 132); Глуви торник - уторак прве недеље Ускршњег поста (Антонијевић 1971: 183; Недељковић 1990: 61); Луда среда - среда прве недеље Ускршњег поста, када се празновало „због главобоље” (СМР: $273)$; Бесне кобиле - период од 9. до 23. марта, за који су везана веровања да је променљиво време, обично карактеристично за овај период, последица игре некаквих бесних коња у облацима (Дебељковић 1907: 262); Мишја субота - субота прве недеље Ускршњег поста, за коју се везује низ ритуалних забрана везаних за рад са тканинама „да их мишеви не би изгризли” (Босић 1996: 218; СМР: 279) итд. ${ }^{10}$

Наведени етнолошки подаци указују на то да је негативна аксиологија овог временског периода утицала на стварање многобројних веровања и митопоетских сижеа о злогуком карактеру самог празника или за њега везаног светитеља. Није, међутим, извесно да се ономасиолошка основа неких од ових хрононима налази у наведеним народним веровањима и ритуалној пракси (тј. Глува недељ $a$ - јер се празнује „од глувоће”), будући да њихова

\footnotetext{
${ }^{7}$ В. Мршевић-Радовић 2008: 138

${ }^{8}$ Елијаде 2007.

9 „Код Срба у Војводини и Румуна у Банату раширено је веровање да ноћу уочи Тодорове суботе иду поворке белих невидљивих коња и њихових јахача који задају страх становништву. Међу коњима било је и хромих који су веома опасни” (СMP: 283).

${ }^{10}$ „Овај празник В. Чајкановић доводи у везу са поштовањем мишјег култа. Познато је да миш представља сеновиту животињу и да се у његовом облику привиђају душе живих и умрлих бића. Зато би мимја субота, јер је субота 'по правилу задушни дан', била 'субота која припада душама"” (Мршевић-Радовић 2008: 131).
} 
древни митопоетски елемент може остати скривен испод метафорички концептуализованог преноса значења.

Пример за то је управо наведени хрононим Глува недеља, о којем пише Драгана Мршевић-Радовић (2008: 129-137)у чланку под насловом Глува недеља у књизи Фразеологија и национална култура. Користећи се обиљем (не само српских већ и других словенских) етнографских и језичких података, она убедљиво доказује да је Глува недеља била и женски празник и празник мртвих, и да је сачувала остатке култа злог женског божанства. Њега је карактерисао низ забрана које се односе на женске послове (да мишеви не једу жито и хаљине), као и на песму, весеље, музику. Улога миша као персонификације бића из хтонског света (животиња, мртвих), од којих жене у овој недељи страхују (празник Мишја субота), посебно је важна, јер се „верује да демонске животиње долазе из рупа у земљи („глувих јама”) и да владају овим болестима - да их изазивају или исцељују будући да су и саме 'глуве'.” (Мршевић-Радовић 2008: 132). ${ }^{11}$ Семантичка структура придева глув одликује се многозначношћу која се развија отуда што каритивна компонента његовог значења може бити испуњена различитим конкретним и апстрактним садржајима, што утиче и на ширење денотативног круга носилаца дате карактеристике (Толстој 2008: 50-53). Међу њима су и појмови из обредне традицијске сфере са значењем посне хране (әлухо јело „пресна, несољена храна", РЈАЗУ III: 207), као и времена, временског периода које карактерише одсуство дневне светлости и извесна хтонска конотативна културна маркираност (упор. општеупотребне синтагме глуво доба, глува ноћ). Она је оспољена и у хрононимима пролећног календарског циклуса везаним за хтонску сферу и култ мртвих (Глува недеља, Глуви уторак, Глува среда). Архаизација митолошког елемента на којем почива номинација овог хрононима утицала је да он буде преосмишљен и да се мотивационо доводи у везу са садржајима за њега везаних обредних веровања. Међутим, његова „културна етимологизација" (термин С. Толстој) указује да је он сам, једном врстом етимолошке магије, могао генерисати обредне радње, веровања или субјекте (тј. Глува недељь - па се празнује „од глувоће”).

Страстна недеља. Последња недеља Великог поста када је, сагласно Новом завету, Христ испаштао за грехе човечијег рода. Назива се и Велика недеља (упор. и хронониме Велики петак, Велики четвртак, Великден „Ускрс" - Плотњикова 2009: 107-108) по великом хришћанском празнику којем претходи. Придев страстна у називу овог хрононима данас је изгубио сакрално значење које је у контексту хришћанске културе задобила мотивна именица * strastb од које се он изводи. Стсл. лексема страсть је, наиме, поред и данас основног значење „страст, похот”, 12 имала и сакрализовано значење

\footnotetext{
${ }^{11}$ Као поткрепљење овог тумачења Д. Мршевић-Радовић наводи језичке податке о семантичкој структури деривационог гнезда придева глув, у којем се срећу и лексеме глушац, глувак, глувач, глуваја као називи хтонских животиња (даждевњак, блавор, миш, пух) (Мршевић-Радовић 2008: 133-134).

12 Упор. стсл. страсть - 1. „страдање, трпљење” страсти радн ннцннхь и въろАъхани'

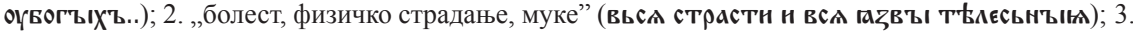


„страдање, трпљење”, „мученички подвиг, мученичка смрт” (СС: 628). Као назив човековог чувства, она је била синонимна са лексемом похоть и означавала је природно човеково осећање (упор. страстн гадъныл и гадовнтыл CC: 628), да би се затим, у хришћанском контексту, семантички обим ове лексеме богатио значењима као што су „трпљење, физичко страдање”, па и „болест, муке” - јер се телесно у супротстављању са духовним сматрало грешним и човек се могао спасити само кроз неко искупитељско страдање, мученички подвиг или мученичку смрт. Са променом културног модела, тј. прелазом од средњовековног теоцентричног на савремени секуларни, потрвена је и веза ова речи са целим комплексом страдања, подвига и искупљења и у савременом језику она има потпуно профано значење (упор. ,а. снажна тежња, необуздан унутрашњи подстицај, нагон ка нечему; осећање јаке телесне привлачности, пожуда; б. јако изражена склоност за нешто, велика приврженост нечему", РСJ: 1275). Трагови старог сакралног значења чувају се и данас у религиозној сфери, тј. у хронониму Страстна недеља, као и у називима дана те седмице (упор. Страстни четвртак, Страстна среда).

\section{3. Ускршњи обредни циклус}

Ускрс. Празник васкрсења Господњег. У стсл. богословским тексто-

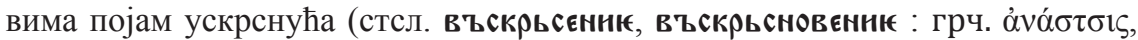
$\varepsilon ้ \gamma \varepsilon \rho \sigma \iota)$ био је првенствено везан за теолошку идеју оживљавања мртвих вољом свемогуће Божије промисли. Међутим, у Синајском псалтиру, једином старозаветном тексту, глаголи въскрьснжтн, въскрьснтн (: грч.

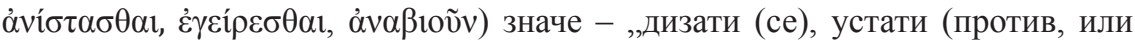

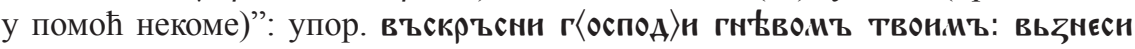

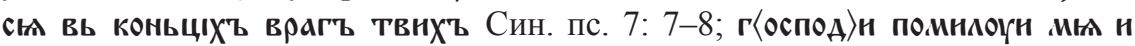
въскрьсн июа и въ弓Аа.иъ ниъ Син. пс. 40: 11.

Старом завету, наиме, није била непозната идеја о васкрсењу, али се она изричито спомиње само на једном месту Кьиге пророка Данила, где се о васкрсењу говори као о буђењу из сна смрти. То схватање се доста разликује од потоње хришћанске догме засноване на веровању да је Христ устао из мртвих за спас људског рода и да његово васкрсење представља победу живота над смрћу (Дрејн 2003: 351).

С друге стране, само васкрсење, у његовој хришћанској форми, било је потпуно непознато и старом, претхришћанском словенству. ${ }^{13}$ У време Христовог васкрсења Словени су многобројним и разноврсним обредима славили буђење природе, те се и Ускрс - попут неких других хришћанских празника

„мученички подвиг, мученичка смрт” (страстъ стаго ижчєннка өөєодора); 4. „страст, похот”:

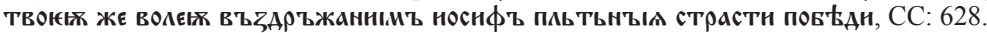

${ }^{13}$ У српском народној приповеци Златоруни ован убијеном јунаку се магијским средствима враћа живот. Чајкановић истиче да је у питању врло архаичан интернационални мотив, по којем ,деутеропотмос, човек који се вратио с онога света, има већу моћ и веће знање, него што је имао раније" (Чудотворни прстен 2001:8). 
који су се само наслојили на изопрагмне паганске - временом почео везивати за словенски народни календар, за празнике пролећно-летњег циклуса и њихове митолошке и обредне садржаје (Агапкина 2002: 106-135). Као покретан празник, Ускрс се обично слави у недељу после првог пуног месеца који следи за пролећном равнодневницом, која је била важан гранични догађај пролећног календарског циклуса (отуда, претпоставља се, и назив Великден, забележен у неким источнословенским и јужнословенским језицима и дијалектима, СД 4: 641.). Зато су сижеи и мотиви везани за народни пролећни календар - мотив обнављања, новог почетка, ритуалног буђења природе (СД 1: 266-267); паљења пасхалних ватри тј. обредних огњева који су симболизовали младо пролећно Сунце које буди природу (СД 3: 621); ритуала обнављања ватре (ватре живе) на кућном огњишту (СД 3: 641-644), итд. - асоцијативно повезивани са хришћанском идејом Христовог васкрсења, дизања, буђења и изласка из света мртвих. ${ }^{14}$ У симболичком језику народне културе глагол васкрснути (ускрснути) јавља се као носилац акционалне културне семантике $^{15}$ (упор. формулу Све нам крсло (оживело) и воскрсло, која се у народу говорила приликом ломљења ускршњег колача, СMP: 293), док је изван ове сфере он примарно везан за идеју Христовог васкрсења (упор. ва̀скрснути - „1. ускрснути, устати из мртвих, оживети (о Христу)”, РСАНУ 2: 419).

Неки етимолози су управо у овим, изразито симболички представљеним народним обредима и веровањима о оживелој природи и њеном ускрснућу из зимског сна (упор. рус. хрононим Вербное воскресенье „празник Врбица"), нашли ономасиолошку основу за тумачење постанка овог хрононима. Метафора која стоји у основи назива Ускрс врло је архаична, тамна и данас мотивационо непрозирна, јер доводи у везу псл. глагол *kresati „кресати, изазивати (ударом, трењем) искре, ватру, огањ" (ЭССЯ 12: 124-125) чењем „стварати, творити, оживотворити”, односно са древним индоевропским представама о живој природи огња. Тако семантички развитак овог глагола тумачи О. Н. Трубачев, који га посматра у оквиру целе лексичко-семантичке групе (*kresati, *kresiti, *kresb, *krasa) и повезује са лат. creô, creâre „саздавати, творити, оживотворити”, истичући примарност значења „створити, саздати” у древној синтагми *kresati ognь (Трубачев 1994: 18). ${ }^{17}$ То би значило да је сам хрононим Ускрс настао онимизацијом првобитног назива за период године у којем је човек пасхалним обредима подражавао и славио њему самом несхватљив, недохватни замах природних, космичких циклуса (оживљавање, буђење природе; почетак новог вегетативног циклуса). Ти об-

\footnotetext{
${ }^{14}$ Паралеле налазимо и у култним текстовима, нпр. у опису васкрсења из XV главе Прве посланице апостола Павла Коринћанима, где се васкрсење доводи у везу са посејаним и умрлим зрном које устаје живо из земље у новом обличју (1. Кор. 15: 35-38).

${ }^{15}$ Упор. ва̀скрс - „ослобођење; поново уздизање, обнављање, препород”; ва̀скрснути - упор. значење 3. „поново се јавити”; 4. „уздићи се на небо” (Онда часни крсти васкрснуше...); 6.а. „оживети некога”; 7. „ослободити; обновити; поново успоставити” и др. ; васкрса́вати - „2.а. поново се јављати, оживљавати"; РСАНУ 2: 418-420).

${ }^{16}$ УПор. срп. кресати „изазивати ватру, огањ, искре; сећи, рубити” (РЈАЗУ V: 523-524; РСАНУ 10: 499-500)

${ }^{17}$ Упор. и Фасмер II: 372. И Буслајев лексему воскресать доводи у везу са представом о вези душе са ватром (Буслајев 2012: 68-69).
} 
реди су истовремено говорили и о сакралном аспекту људске егзистенције, тј. човековој потреби да паљењем пасхалних ватри симболично представи и своје учешће у стваралачким догађајима у природи и своје слутње о неизмерности и апсолутности космичко-божанских начела. Христовом васкрсењем се само обновила стара сакрална форма, обредно поступање сменило је хришћанско веровање, али је са дна свих тих сажетих форми просијавала архетипска идеја о кружности и стабилности тока природног, људског и божанског времена.

Иако почивају на различитим премисима - словенски народни калндар прати динамику природних и пољопривредних циклуса током календарске године, док је хришћански почива на значајним догађајима Христове личне историје или на значајним епозодама из живота светих - ова два календара су у српској и словенској обредној традицији нераздвојиво повезана, а њихови основни празнични периоди испреплитани сижеима и мотивима и једне и друге културне традиције. То је посебно било каркатеристично за пасхални циклус (паљење нове ватре на огњишту на Страстну суботу; обилажења поља са обредним хлебом украшеним приказом лестава којима се Христ „узнео на небо”; паљење пасхалних ватри с циљем „буђења” или „подизања” Христа са споменом на апостоле који су, очекујући васкрсење Христово, седели и грејали се код ватре, итд.) (Агапкина 2002: 702-705). Ово укрштање мотива обележило је и стваралаштво неких хришћанских проповедника и писаца као што су Григорије Богослов, Кирил Туровски и Лав Аникита Филолог који су, сваки у свом времену, у жанру средњовековних „слова” оставили и кратке описе пролећа у којима је симболика пролећног обнављања природе семантички и симболички доведена у везу са радошћу због Христовог васкрсења које се слави (Бегунов 1976: 269-277). Из чланка наведеног аутора навешћемо само неколико стихова из слова Лава Аниките Филолога ${ }^{18}$ ради илустрације: Ныне весна красна, / весна духовна, / весна душам, / весна телесем, / весна видимая, / весна невидимая... (Бегунов 1976: 275).

3.1. Истраживање етнолингвистичких карактеристика хрононима пролећног календарског периода, вршено на материјалу одабраних лексема масленичког, великопосног и ускршњег обредног циклуса, омогућило је постављање неколико основних закључних теза:

a) Због тога што кондензују и конзервирају многе архаичне особине језика и културе, хрононими представљају драгоцен извор за реконструкцију старих словенских духовних традиција. То посебно важи за онај њихов слој чији древни митопоетски семантички и симболички садржаји остају скривени под слојем народном етимологијом преосмишљених назива, или се мењају под утицајем хришћанства.

${ }^{18}$ У Слову на Пасху и у спомен преподобног и богоносног оцуа намег Зосима чудотоворияа (1534-1538) Лав Аникита Филолог саставио је према Григорију и Кирилу нови запис о пролећу одредивши га као „плетение глагол”. 
б) Проучавање етнокутурног контекста у којем речи функционишу веома је важно јер се назив празника или празничног периода често може довести у формалну и семантичку везу са одређеним обредним радњама и веровањима које су за њега карактеристичне и чијим су митопоетским доминантама били мотивисани и неки од ових назива (Коњски великден, Хрома) трапава недеља, Бесне кобиле и сл.). Истраживање дубљих етнокултурних слојева у некима од њих, међутим, показује да су заправо, у низу случајева сами називи генерисали обичајне радње и веровања. То је најкарактеристичније за празнике у којима се појављује етнокултурни мотив тзв. лошег времена, односно прелазног календарског периода (упор. Бела недељь, Глуха недеља, Луда недеља и сл.).

в) Узроци који доводе до тога је да је првобитна семантичка или формална мотивација неких од ових онима за говорника српског језика данас непрозирна могу бити различити: током историје језика била је изгубљена или архаизована њихова мотивна реч (Покладе); био је промењен аксиолошки параметар симболичке компоненте њиховог значења (Бела недеља); старо значење добило је нова тумачења у оквиру обновљене сакралне форме (Чиста недеља, Великден) или се изгубило под утицајем дуго времена преовлађујућег секуларног културног модела (Страстна недеља). Хрононим Ускрс данас је мотивационо непрозиран јер је непрозирна његова „културна етимологија". Његов древни митопоетски елемент (животворућа природа огња) остао је скривен испод културно концептуализованог преноса значења који буђење и оживљавање природе доводи у везу са централним догађајем нове религије: Христовим васкрснућем.

г) Анализа овог слоја обредне лексике показала је да хрононими имају и различите културне функције, међу којима је врло изразита она која почива на принципима етимолошке магије: хрононими својим семантичко-симболичким садржајем могу мотивисати обредне радње и веровања.

3.2. Обредна лексика српског језика није код нас систематичније етнолингвистички проучавана ни у оквирима одређеног семантичког поља (обредни календарски комплекси какви су покладни, ускршњи, тројички, ивањданско-петровски, божићњи и сл.) ни у оквиру одређене лексичко-семантичке групе лексема (хрононими, називи обреда, ритуалних предмета, радњи, митолошких персонификација, лица која врше или над којима се врше ритуалне радње итд.). Добру полазну основу за овакву врсту истраживања представљају Материјали за етнолингвистичко изучавање балканословенског ареала А. А. Плотњикове, који би се могли допунити грађом из богате збирке српских етнолошких и фолклорних извора како би истраживањем био обухваћен цео српски језички простор. Веома би било важно и да се у дијалекатским истраживањима српских народних говора овај лексици да посебно место, поготову зато што је све мање оних људи који старе српске календарске обреде чувају у свом сећању или примењују у свакодневном животу. Систематично сређивање ове лексичке грађе омогућило би многа и богата трагања, не само у оквиру српског или карпато-балканског језичког и културног простора него и у општесловенској перспективи. 


\section{ЛИТЕРАТУРА}

Агапкина 2002: Т. А. Агапкина, Мифопоэтические основы славянского народного календара. Весенне-летный циикл, Москва: РАН, Институт славяноведения.

Антонијевић 1971: Д. Антонијевић, „Алексиначко Поморавље”, СЕЗб LXXXIII, књ. 35, Београд: САНУ.

Бегунов 1976: Бегунов, „Три описания весни”, у: Зборник историје књижевности. Стара српска књижевност, књ. 10, Београд: САНУ, 269-277.

Босић 1996: М. Босић, Годишњи обичаји Срба у Војводини, Београд: Студио дизајн.

Буслајев 2012: Ф. И. Буслаев, О влиянии христианства на славянский язык, Москва: ЛИБРИКОМ [1. изд. 1848].

Дебељковић 1907: Д. Дебељковић, „Обичаји српског народа на Косову пољу", СЕЗб VII, књ. 4, Београд: СКА.

Ђорђевић 1958: Д. Ђорђевић, „Живот и обичаји народни у лесковачкој Морави", CEЗб LXX, књ. 31, Београд: САНУ.

Дрејн 2003: Џ. Дрејн, Увођење у Стари завет, Београд: Clio.

Елијаде 2007: M. Elijade, Mit o vječnom povratku, Zagreb: Naklada Jasenski i Turk.

Зељењин 1995: Д. К. Зеленин, Избранные труды. Очерки русской мифологии, Москва.

Костић1988/89: П. Костић, „Годишњи обичаји (Сјеничко-пештерска висораван)", ГЕМБ, књ. 52-53, Београд: Етнографски музеј, 73-123.

Мршевић-Радовић 2008: Д. Мршевић-Радовић, Фразеологија и национална култура, Београд: Друштво за српски језик и књижевност Србије.

Недељковић 1990: М. Недељковић, Годишњи обичаји у Срба, Београд: Вук Караџић.

Петровић 1948: П. Петровић, „Живот и обичаји народни у Гружи”, СЕЗб LVIII, књ. 26, Београд: СКА.

Плотњикова 2009: А. А. Плотникова, Материаль для этнолингвистического изучения балканославянского ареала, Москва: РАН, Институт славяноведения.

Раденковић 1996: Љ. Раденковић, Симболика света у народној магији јужних Словена, Ниш.

PJA3У - Rječnik hrvatskoga ili srpskoga jezika, Zagreb: Jugoslavenska akademija znanosti i umjetnosti, 1880-1882/1975-1976.

РСАНУ - Речник српскохрватског књижевног и народног језика, том 1-, Београд: САНУ, 1959-.

PCJ - Речник српскога језика, Нови Сад: Матица српска, 2007.

СД - Славянские древности: Этнолингвистический словарь, т. 1-5, Москва: РАН, Институт славяноведения, 1995-2012.

СМР - Ш. Кулишић, С. Петровић, Н. Пантелић, Српски митолочки речник, Београд: Нолит, 1970.

Срезњевски 1989: И. И. Срезневский, Словарь древнерусского языка [репринтное издание], том I-IV, Москва: Книга. 
СП - Свето писмо Старога и Новога завјета (прев. Ђ. Даничић, В. Ст. Караџић), Београд: Британско и инострано библијско друштво, 1993.

$\mathbf{C C}-$ Старославянский словарь, по рукописям X-XI веков, Москва: Русский язык, 1994.

Толстој 1988: С. М. Толстој, „О међусобном односу хришћанског и народног календара код Словена: рачунање и вредновање дана недеље", Повеља, год. 18, бр. 1/2, Београд, 119-132.

Толстој 2008: С. М. Толстая, Пространство слова. Лексическая семантика в опщеславянской перспективе, Москва: РАН, Институт славяноведения.

Толстој/Толстој 2013: Никита И. Толстой, Светлана М. Толстая, Славянская этнолингвистика. Вопросы теории, Москва: РАН, Институт славяноведения.

Тројановић 1930: С. Тројановић, Ватра у обичајима и животу српског народа, Београд: СКА.

Трубачев 1994: О. Н. Трубачев, Праславянское лексическое наследие и древнерусская лексика дописьменного периода, Этимология 1991-1993, Москва, 3-23.

Фасмер 1986/1987: М. Фасмер, Этимологический словарь русского языка, I-IV, Москва: Прогресс.

Филиповић 1939: М. Филиповић, „Обичаји и веровања у Скопској котлини”, CEЗб LIV, књ. 24, Београд: СКА, 277-566.

Чудотворни прстен 2001: Чудотворни прстен: најлепше српске народне приповетке (ур. В. Чајкановић), Ниш: Просвета.

Шкарић 1939: М. Шкарић, „Живот и обичаји 'планинаца' под Фрушком Гором", CEЗб LIV, књ. 24, Београд: СКА, 1-275.

ЭССЯ: Этимологический словарь славянских языков [ред. О. Н. Трубачев], том 1-, Москва: Наука, 1974-.

Snežana P. Vučković

ETHNOLINGUISTIC FEATURES OF CERTAIN CHRONONYMS OF THE SPRING CEREMONIAL CYCLE

\section{Summary}

Ethnolinguistic research of chrononyms of the spring ceremonial cycle has shown that many archaic features of the Serbian language and culture are conserved and condensed in these lexemes. That is why they are a very important source for reconstructing Old Church Slavonic spiritual culture, especially its layer whose ancient mythopoetic semantics remained hidden under the layer of names re-imagined by folk etymology, as well as those whose semantic and symbolyc contents changed under the influence of the Christian culture and its rules. 